\title{
FROM LITERACY TO FINANCIAL EDUCATION: A SURVEY OF METHODS TO MEASURE PHENOMENA. THE PARTICULAR SITUATION OF ROMANIA
}

\author{
Adela Socol ${ }^{1}$
}

\begin{abstract}
People with a high level of financial literacy represent a premise for the societies' evolution and wellbeing, because informed citizens are capable to manage their money, to take proper financial decisions and to contribute to general prosperity and financial stability. We analysed the ideological acceptations of the basic concepts and the methodology of measuring financial literacy. The paper emphasizes on the problem of low financial literacy across countries. This problem could be solved by developing a national strategy of financial education that is the premise for efficient financial education.
\end{abstract}

Keywords: Financial Literacy, Financial Education, Methodologies to measure, Financial Behavior

JEL Codes: D03, G02, I22

\section{Introduction}

The shortage of personal financial education is believed to have facilitated the increase in credit debts, which in February 2014 represented 22.52\% of the non-performing loans, according to Monthly Bulletin issued by the National Bank of Romania. Not only credit debts can be affected by the low level of the financial literacy.

Financial literacy could be obtained through the financial education process. People's needs to be financially educated represent a burning actual subject for humans from everywhere, especially after 2008, in the international financial crisis context. The answers to the questions How can be people able to make proper financial decisions? Does financial literacy assure proper financial behavior? Could be people financially educated to plan and manage financial problems? Who have to be financially educated and what is the stage of people's existence when the financial education is adequate? concern the governmental agencies, the business community and individuals, especially in the last years, when the financial issues became an integral part of today's world. People have to be capable to manage their personal and family's budget, to understand the essence of the money and banks and to make the difference between consumptions and investments.

Debates related to financial education and literacy have grown ardently just in the middle of years 2000, when it became obvious that populations/citizens have low levels of financial literacy and can make financial mistakes, that affect their savings, investments, debts and surely, their entire lives.

This article tries to draw attention towards the low level of financial literacy in Romania, measured by the Financial Literacy Index (31 on a scale between 1 and 100). The low level of financial literacy of general population in Romania was presented in the last published survey on financial literacy (Stănculescu, 2010). Basic concepts in the area are "financial literacy", "financial education" and "financial capability". They are studied in a paper belonging to Stănculescu (2010), which considered that the mentioned concepts are related, but they are not similar. Based on specialised literature, we observed that knowledge and skills are considered the most important

1 "1 Decembrie 1918” University of Alba Iulia, Nicolae Iorga Street, 11-13, Alba Iulia, Romania, email:

adelasocol@yahoo.com 
when there are created templates to measure financial literacy and financial education. We consider that the behavioural element of financial capability should be acknowledged at the development of models to measure financial literacy and financial education. General acceptation of financial literacy concept is associated with the level of knowledge and understanding of financial issues of people, while financial education syntagma is related to formal or informal, scholarly or nonscholarly educational programmes offered with the purpose of increasing the level of financial literacy.

We consider that Romania made in the last period some important steps in financial education programs. Proof of this implication is the success of Romania that was designated winner of "Global Money Weed Award" for Europe, on 22 May 2014. The project of Romania was developed by the National Bank of Romania in partnership with Ministry of Education in the area of financial education of children and young people from Romania. More than 6100 students and approximately 360 teachers from 124 schools across Romania took part in the awarded project (GMW, 2014).

\section{Objectives and the research methodology}

We set the specific objectives of the research in the identification of the defining elements of the "financial literacy" and the related concepts - financial education, financial capabilities and financial behavior, studying the existing strategies for measuring financial literacy from the relevant published papers and analyzing the Romania's situation in the terms of financial literacy and education.

First, we study the ideological acceptations of basic concepts of financial literacy and comment the definitions and key-concepts - financial knowledge, skills, abilities, behavior and experiences. We annotate on the methods of measuring financial literacy, investigating how they are developed and what the common items of questionnaires that investigate financial literacy are. Also, we identify main national surveys that tried to measure the financial literacy of people from different countries.

The particular situation of Romania was analyzed based on typology of financial literacy versus financial education and behaviour. Financial education needs was an important task in our research because they represent the fundamental issue in developing the national financial education or literacy system. Staying informed about financial issue contributes to the capability to manage financial matters in diverse situation of people's life.

Our approach belongs to interpretive current and critical analysis of the financial education subject. The paper argues for the adequate financial education and promotes the importance of people's financial literacy in order to contribute to their abilities and skills in understand monetary and financial aspects of anyone's life.

\section{Theoretical background on the financial literacy and education}

Literature on financial literacy was scanty before 2000 and we can record only few incipient studies in the domain, taking into account the weak concerns of national authorities to measure the phenomenon in the different countries. Studies and national cares have grown rapidly after 2000, when the stage of knowledge increased based on the economies' and financial products' complexity. Financial markets have became more sophisticated in the last years and it contributes to the people's financial inability in understand the market mechanism or managing their budgets.

In the European Union, since 2000, the importance of proper financial education has been recognized and the subject was discussed in the White Paper on Financial Services Policy (20052010) and later, in 2007, in the Green Paper on Retail Financial Services (Commission of the European Communities, 2007). The studies underline how important financial education is. The advantages of financial education are grouped depending on the people's category - children, students and young people, adults or citizens. Financial education contributes to the improvement of 
people's ability, as follows:

- Children will better understand the role of money and they will be primary educated in budgeting and saving;

- Students and young people will develop the capacity to manage their money and specific loans;

- Adults will plan more carefulfy major financial events as buying a residence or financial aspects regarding becoming parents;

- Generaly, citizens can be helped in the developing of the abilities to make financial provision, especially for unforeseen situations. Also, financial education can contribute to the people's choice for their retirement or particular needs, like responsible selections of financial services or products. A proper financial education improves people's ability to distinguish the payment fraud potential situation.

In the United States of America, illiteracy has been recognized as an important issue that could affect everyone, irrespectively of gender, age, socio-economic category or race. Also, the illiteracy is considered an item that upsets the economic future of USA (PACFL, 2008).

The topic of financial education stirred the involvement of the OECD, which completed in 2012 an International Network on Financial Education (INFE) Pilot Study (Atkinson and Messy, 2012). It presents the situation of 14 countries, across 4 continents: Albania, Armenia, Czech Republic, Estonia, Germany, Hungary, Ireland, Malaysia, Norway, Peru, Poland, South Africa, United Kingdom, and British Virgin Islands. The questionnaires analyzed the levels of financial knowledge, behaviour and attitudes towards long term financial plans. These studies contributed to the improvement of knowledge in the area. They identified needs and gaps in financial education of people and promoted ideas for national policies and strategies in financial education domain. Findings of the studies were alarming, because the majority of people have the core financial knowledge, but without understand the usual concepts, like the interest paid on a loan, the compound interest or the stock market products. If people improve their financial knowledge, this can contribute to the positive financial behavior or attitudes.

In 2012, the leaders of G20 recognised how important financial education is and sustained the High-level Principles on National Strategies for Financial Education (OECD, 2012). Also, G20 required OECD/INFE and the Word Bank to develop the tools to promote the financial education. As a consequence, in September 2013 the OECD and INFE issued a guide "Toolkit to measure the financial literacy and financial inclusion: Guidance, core questionnaire and supplementary questions" (OECD, 2013). The mentioned study is useful for the public authority and other organizations that are helped to collect the data regarding to the measure of financial literacy, inclusive in terms of key socio-demographic groups.

Literature refers to financial literacy as increasing concern to government and other public policy makers, taking into account that the surveys in OECD countries found that financial literacy is very low amongst individuals and households irrespective of income and education, but especially amongst groups with lower income and less education (Altman, 2012).

The most studied relationships between the financial literacy and behavior refer to the participation on the stock market and to non-payment consumer credit debts. Lower level of the financial literacy of people was associated in the empirical studies with the limited participation in the stock market and preparation for the retirement (Gathergood, 2012). The author analyzed the relationship between self-control and financial literacy and over-indebtedness on consumer credit debt in UK. His results suggest that poor financial literacy is positively associated with overindebtedness.

Also, the financial literacy was analyzed in correlation with the consumer credit portfolios in the UK's case and shows us that poor financial literacy borrowers have lack confidence when they analyze the credit terms and express confusion over financial concepts (Disney and Gathergood, 2013). 
How economic literacy influences the relationship between inequality and finance was studied by Lo Prete (Lo Prete, 2013), which found that in countries where economic literacy is higher, the income inequality grows less.

Recent approach of the importance of financial literacy to management of personal finances in a young household was developed for Lithuania by Navickas (Navickas et. al, 2014). They found that the level of financial knowledge in young Lithuanian households is low and this affect people's ability to manage their personal finance. The level of financial literacy among the high school students in a region of the Czech Republic was studied by Pasekova (Pasekova et. al, 2013) and they found that the financial literacy of students in the Czech Republic is not sufficient.

In June 2013, OECD/INFE published a study related to the national strategies for financial education, according to which forty-seven countries have already start the process to develop a national strategy for financial education (OECD, June 2013:14). According to the mentioned OECD study, the following twenty-tree countries have implemented a national strategies or have approved one and are moving to implementation: Australia, Brazil, Czech Republic, El Salvador, Estonia, Ghana, India, Ireland, Japan, Malaysia, Mexico, Netherlands, New Zealand, Nigeria, Portugal, Russian Federation, Singapore, Slovenia, South Africa, Spain, United Kingdom, United States, Zambia. Twenty-four countries started considering and/or designed a national strategy for financial education, but not yet implemented it: Armenia, Canada, Chile, China, Colombia, Indonesia, Israel, Italy, Kenya, Latvia, Lebanon, Malawi, Morocco, Peru, Poland, Romania, Serbia, South Korea, Sweden, Tanzania, Thailand, Turkey, Uganda, Uruguay (OECD, June 2013:14).

\section{Analyses of strategies for measuring the financial literacy}

We based our paper on the "financial literacy" syntagm, considering that is adequately stresses the essential intended meanings - the essential ability to "read and write" in financial domain. We have chosen the "financial literacy" term as the subject of our approach with the purpose to underline the opposite status with illiteracy or analphabetism. In the Table no. 1 we present the relevant acceptations of the financial literacy/education.

Table no. 1

Conceptual definitions of "financial literacy/education"

\begin{tabular}{|c|c|c|}
\hline Authors and Year & $\begin{array}{c}\text { Key } \\
\text { element }\end{array}$ & Significance \\
\hline OECD, 2005 & $\begin{array}{l}\text { Financial } \\
\text { education }\end{array}$ & $\begin{array}{l}\text { "Process by which individuals improve their understanding of } \\
\text { financial products and concepts; and through information, } \\
\text { instruction and/or objective advice develop the skills and } \\
\text { confidence to become more aware of financial risks and } \\
\text { opportunities, to make informed choices, to know where to go } \\
\text { for help, and to take other effective actions to improve their } \\
\text { financial well-being and protection" }\end{array}$ \\
\hline $\begin{array}{l}\text { PACFL (President's } \\
\text { Advisory Council on } \\
\text { Financial Literacy)- } \\
\text { USA, 2008 }\end{array}$ & $\begin{array}{l}\text { Financial } \\
\text { literacy }\end{array}$ & $\begin{array}{l}\text { "Ability to use knowledge and skills to manage financial } \\
\text { resources effectively for a lifetime of financial well-being" }\end{array}$ \\
\hline $\begin{array}{c}\text { PACFL (President's } \\
\text { Advisory Council on } \\
\text { Financial Literacy)- } \\
\text { USA, } 2008\end{array}$ & $\begin{array}{l}\text { Financial } \\
\text { education }\end{array}$ & $\begin{array}{l}\text { "Process by which people improve their understanding of } \\
\text { financial products, services and concepts, so they are } \\
\text { empowered to make informed choices, avoid pitfalls, know } \\
\text { where to go for help and take other actions to improve their } \\
\text { present and long-term financial well-being" }\end{array}$ \\
\hline $\begin{array}{l}\text { Dvorakova, 2009, } \\
\text { cited by Tomaskova }\end{array}$ & $\begin{array}{c}\text { Financial } \\
\text { literacy }\end{array}$ & $\begin{array}{l}\text { "A set of knowledge, skills and attitudes of citizens necessary } \\
\text { to financially secure themselves and their family in }\end{array}$ \\
\hline
\end{tabular}




\begin{tabular}{|c|c|l|}
\hline Authors and Year & $\begin{array}{c}\text { Key } \\
\text { element }\end{array}$ & \multicolumn{1}{|c|}{ Significance } \\
\hline et al., 2011 & & $\begin{array}{l}\text { contemporary society. They are actively performing in the } \\
\text { market of financial products and services. Financially literate } \\
\text { citizens are well versed in issues of money and prices, and are } \\
\text { able to responsibly manage their personal or family budget, } \\
\text { including the management of financial assets and financial } \\
\text { liabilities with regard to changing life situations" }\end{array}$ \\
\hline $\begin{array}{c}\text { Atkinson and Messy, } \\
\text { 2012 }\end{array}$ & $\begin{array}{c}\text { Financial } \\
\text { literacy } \\
\text { Altman, 2012 }\end{array}$ & $\begin{array}{l}\text { Financial } \\
\text { behaviour necessary to make sound financial decisions and } \\
\text { ultimately achieve individual financial wellbeing" }\end{array}$ \\
\hline Mihalcova et al., & $\begin{array}{l}\text { Financial } \\
\text { literacy } \\
\text { responsible financial decisions" }\end{array}$ & $\begin{array}{l}\text { "Ability to use knowledge, skills and experience of an } \\
\text { individual to make effective decisions regarding the use and } \\
\text { management of their own finances to provide life-long } \\
\text { financial security for themselves and their families" }\end{array}$ \\
\hline $\begin{array}{c}\text { Remund, 2010 cited } \\
\text { by Bay et al., 2014 }\end{array}$ & $\begin{array}{c}\text { Financial } \\
\text { literacy }\end{array}$ & $\begin{array}{l}\text { "Five categories of various definitions of financial literacy: (1) } \\
\text { Knowledge of financial concepts (2) Ability to communicate } \\
\text { about financial concepts (3) Aptitude in managing personal } \\
\text { finances (4) Skill in making appropriate financial decisions (5) } \\
\text { Confidence in planning effectively for future financial needs" }\end{array}$ \\
\hline
\end{tabular}

Studying chronologically the relevant approach of the conceptual definitions of financial literacy, we remark that the initial concepts are based on the knowledge and skills, while the recent approaches focus on the ability to make sound financial decisions.

Financial education is considered a process that stands at the base of forming the financial literate persons. Also, financial education implies actions through which people improve their understanding of financial concepts and products.

The general meaning of financial literacy revolves around the abilities and skills of using and applying financial knowledge, which refers to information about legal aspects, numerical information or descriptive ones. All these aspects suggest that financial literacy highlights in a specific manner financial behavior and financial experiences, which are defining a person called "financial literate".

General assumptions of the research in the financial literacy domain considered that there is a link between financial literacy and behavior, but the intensity and the direction of this link represent a research challenge, which arouse the interest of many scientists, starting with economists and philosophers. Some authors (Jappelli and Padula, 2013) considered that the general assumptions referring to financial literacy have to be completed with the following approach: "The financial literacy is a choice and that in choosing how much to invest to acquire financial literacy, consumers trade-off costs and benefits". They considered that mathematical ability acquired earlier in life influence the future trajectories of financial literacy.

Concerns regarding the financial education process can be identified in many countries, generated by the growing rate of indebtedness of households and by the significant number of nontransparent financial markets' products (Case of Czech Republic - Chlouba et al., 2011; Case of Slovak Republic - Zvarikova and Majerova, 2014; Case of Russia - Klapper et al., 2013). National experiences in the financial literacy studying were recorded since ' 90 years, when in the United Kingdom was conducted the first research projects on levels of financial literacy by National Foundation for Education Research (World Bank, 2009). Until now, many national surveys on financial literacy were developed, especially after 2000. 
The World Bank conducted in 2008-2009 in Romania a survey on financial literacy Diagnostic Review on Consumer Protection and Financial Literacy, subsequent to similar studies conducted in Czech Republic, Slovakia, Azerbaijan, Croatia, the Russian Federation, Lithuania and Bulgaria (Stănculescu, 2010). The objectives of the study (World Bank, 2009) were to:

- establish proper practices for evaluating consumer protection and financial literacy;

- identify the existing rules and practices in Romania related to financial education; and

- conclude on methods to improve consumer protection and financial literacy in Romania.

The questionnaires were applied on 2425 persons (only 2048 completed the questionnaires), that consists in a representative sample at the national level (error $+/-3 \%$, confidence level 95\%).

Table no. 2 presents the key items of the methodology for measuring the financial literacy, based on the Financial Literacy Index FLI, computed similarly to the UK model of financial capability, which uses the following scores:

- Knowledge and understanding

- Skills

- Attitudes and confidence

- Behaviour - participation in the financial system

Table no. 2

Relevant methodologies of measuring financial literacy in Romania

\begin{tabular}{|c|c|l|l|}
\hline $\begin{array}{c}\text { Authors and } \\
\text { Year }\end{array}$ & Indicator & \multicolumn{1}{|c|}{ Items } & \multicolumn{1}{|c|}{ Measurement strategy } \\
\hline $\begin{array}{c}\text { Stănculescu, } \\
2010\end{array}$ & $\begin{array}{c}\text { Financial } \\
\text { Literacy Index } \\
\text { FLI }\end{array}$ & $\begin{array}{l}\text { Knowledge and } \\
\text { understanding } \\
\text { financial issues }\end{array}$ & $\begin{array}{l}\text { Score obtained to a quiz of eight } \\
\text { questions that test applied financial } \\
\text { literacy }\end{array}$ \\
\cline { 3 - 4 } & General information & $\begin{array}{l}\text { Factor score of six questions on how } \\
\text { frequently person uses to inform from } \\
\text { various mass media sources }\end{array}$ \\
\cline { 3 - 5 } & Financial information & $\begin{array}{l}\text { The share of financial indicators people } \\
\text { generally monitor using a large range of } \\
\text { sources }\end{array}$ \\
\cline { 3 - 4 } & $\begin{array}{l}\text { Trust in financial } \\
\text { institutions }\end{array}$ & $\begin{array}{l}\text { Score obtained using seven questions } \\
\text { regarding trust in financial institutions }\end{array}$ \\
\cline { 3 - 4 } & $\begin{array}{l}\text { Participation in the } \\
\text { financial system }\end{array}$ & $\begin{array}{l}\text { Number of different type of formal } \\
\text { financial products people use }\end{array}$ \\
\hline
\end{tabular}

In the following figure, we have presented the Financial Literacy Index for Romania (31 on a scale between 0 and 100) that was considered in four clusters - outsider, reluctant, adopter and follower - depending on deviation from the mean values. The results are based on the survey regarding to the financial literacy, prepared for the World Bank by the Romanian Institute for the Study of the Quality of Life (Stănculescu, 2010). 


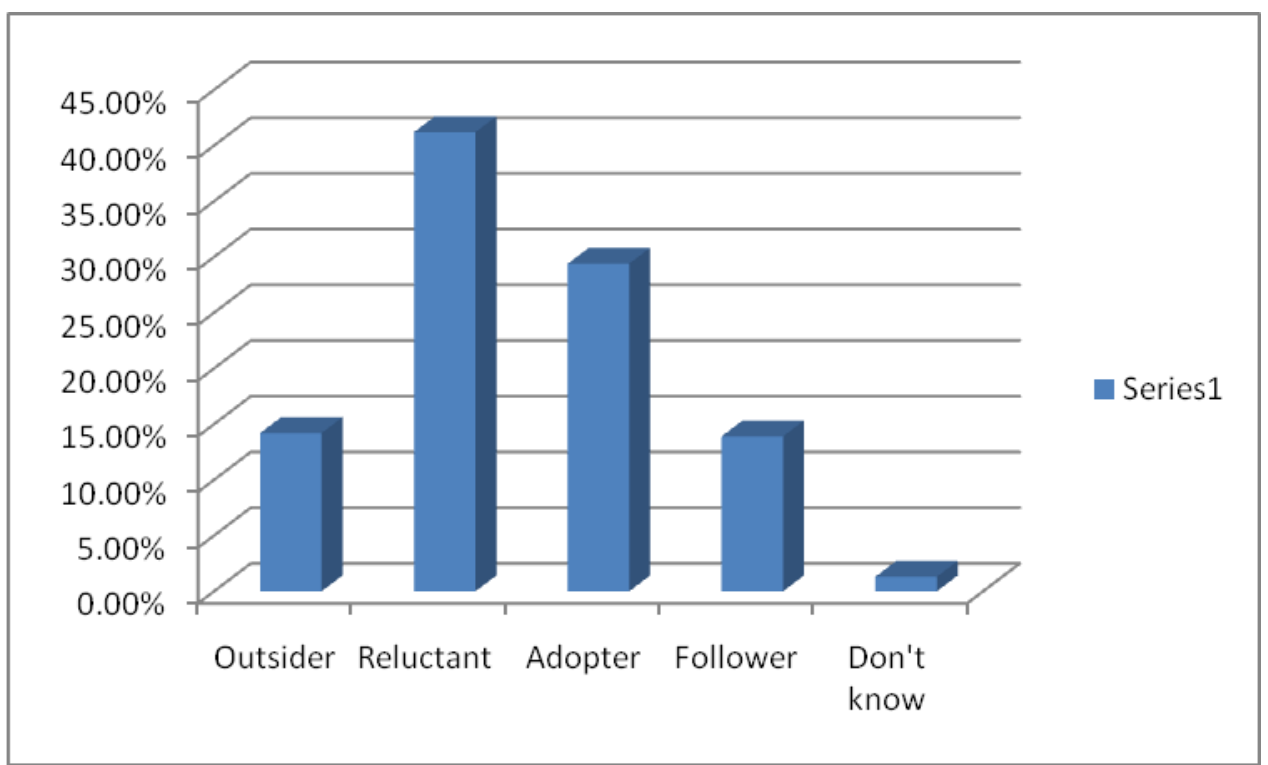

\section{Figure no. 1 - Financial Literacy Index (FLI) in Romania and the financial literacy types}

Source: Stănculescu M. S., 2010. Analysis of the Financial Literacy Survey in Romania and Recommendations, Comprehensive Report prepared for the Word Bank, p. 14

\section{Conclusions}

In this paper, we have analyzed the conceptual terms in financial literacy domain and have observed the prevalence in the specialized literature of the following acceptations: the abilities and skills to use and apply the financial knowledge that are information about legal aspects, numerical information or descriptive ones. These acceptations characterize a person that is calling "financial literate".

The paper draws on the recent national studies on financial literacy and underlines their results, which consist in very low level of knowledge and understanding of financial matters of general population. Comparing the different national results of the surveys on financial literacy represent a difficult task, because a general internationally harmonized methodology to measure the level of financial literacy does not exist. So, one national data set has to be studied separately from other results. So, one national data set have to be studied disparate from another results of others countries and this affect the comparability of data in the same time and between countries or regions.

We found incipient concerns in Romania referring to the financial literacy measurement, based on the World Bank's survey on financial literacy, conducted in 2008-2009 - Diagnostic Review on Consumer Protection and Financial Literacy. Its results suggest the low level of financial literacy of general population in Romania, based on the Financial Literacy Index (31 on a scale between 1 and 100). Although six years have passed since the mentioned survey, in Romania, there is no national strategy for financial education which could provide learning opportunities for people. Such strategy has to be based on the principle of financial education that must to be available and actively promoted at all stages of life on a continuous basis.

In this paper, we comment on defining of the financial literacy and investigate how the financial literacy was studied in the relevant papers. Also, we report on current national approaches in the measurement of financial literacy. So, our study contributes to the creating of a general framework of financial literacy and education in Romania. Also, we militate in favor of financial education programs and we contribute to conscience of proper financial education during the life.

Governments' efforts to improve the level of financial literacy amongst citizens were very justified and have increased in the last years. Governments and social institutions have convinced 
themselves that a financial literate person is capable to manage their personal and family's budget, to understand the essence of the money and banks and to make the difference between consumptions and investments. Unfortunately, a low level of financial literacy is associated with negative aspects of financial behavior, as the credit debts, the delusive retirement plans, the poverty or the people's inability to manage their personal finances.

\section{References}

1. Altman M., 2012. Implications of behavioural economics for financial literacy and public policy, The Journal of Socio-Economics, Vol. 41, pp. 677-690

2. Atkinson A., Messy F., 2012. Measuring Financial Literacy: Results of the OECD / International Network on Financial Education (INFE) Pilot Study, OECD Working Papers on Finance, Insurance and Private Pensions, No. 15, OECD Publishing. http://dx.doi.org/10.1787/5k9csfs90fr4-en

3. Bay C., Catasus B., Johed G., 2014. Situating financial literacy, Critical Perspectives on Accounting, No. 25, pp. 36-45

4. Chlouba T., Simkova L., Nemcova Z., 2011. Application for education of financial literacy, Procedia - Social and Behavioral Sciences, No. 28, pp. 370-373

5. Commission of the European Communities, 2007. Communication from the Commission Financial Education, Brussels, p. 2

6. Disney R., Gathergood J., 2013. Financial literacy and credit consumer portfolios, Journal of Banking \& Finance, No. 37, pp. 2246-2254

7. Gathergood J., 2012. Self-control, financial literacy and consumer over-indebtedness, Journal of Economic Psihology, No. 33, pp. 590-602

8. Global Money Week 2014, http://globalmoneyweek.org/Countries/romania.html

9. Jappelli T., Padula M., 2013. Investment in financial literacy and saving decisions, Journal of Banking \& Finance, No. 37, pp. 2779-2792

10. Klapper L., Lusardi A., Panos G.A., 2013. Financial literacy and its consequences: Evidence from Russia during the financial crisis, Journal of Banking \& Finance, No. 37, pp. 3904-3923

11. Lo Prete A., 2013. Economic literacy, inequality, and financial development, Economic Letters, No. 118, pp. 74-76

12. Mihalcova B., Csikosova A., Antosova M., 2014. Financial literacy - the urgent need today, Procedia - Social and Behavioral Sciences, No. 109, pp. 317-321

13. Navickas M., Gudaitis T., Krajnakova E., 2014. Influence of financial literacy on management of personal finances in a young household, Business: Theory and Practice, No. 15 (1), pp. 32-40

14. OECD, 2005. Recommendations on Principles and Good Practices for Financial Education and Awareness, http://www.oecd.org/finance/financial-education/35108560.pdf

15. OECD/INFE, August 2012. High-level Principles on National Strategies for Financial Education, http://www.oecd.org/finance/financial-education/OECD_INFE_High_Level _Principles_National_Strategies_Financial_Education_APEC.pdf

16. OECDINFE, June 2013. Current status of national strategies for financial education, http://www.oecd.org/daf/fin/financial-

education/TrustFund2013_OECD_INFE_Current_Status_of_National_Strategies_for_Fin_E d.pdf

17. OECD/INFE, September 2013. Toolkit to measure the financial literacy and financial inclusion: Guidance, core questionnaire and supplementary questions, http://www.oecd.org/daf/fin/financial-education/TrustFund2013_OECD_INFE_toolkit to_measure_fin_lit_and_fin_incl.pdf 
18. PACFL - USA President's Advisory Council on Financial Literacy, 2008. Annual report to the President, http://www.jumpstart.org/assets/files/PACFL_ANNUAL_REPORT_1-1609.pdf

19. Pasekova M., Redinova H., Oprean V., Kallaste K., Homolka L., Blechova B., Sobotovicova S., 2013. The Level of Financial Litercy among the High School Students in the chosen regions of the Czech Republic, International Journal of Mathematical Models and Methods in Applied Sciences, Issue 4, Vol, 7, pp. 462-469

20. Remund D.L., 2010. Financial literacy explicated: the case for a clearer definition in an increasingly complex economy, Journal of Consumer Affairs, No. 44, pp. 276-295

21. Stănculescu M.S., 2010. Analysis of the Financial Literacy Survey in Romania and Recommendations, Comprehensive Report prepared for the World Bank, http://siteresources.worldbank.org/INTECAREGTOPPRVSECDEV/Resources/Romania_Fi nancial_Literacy June_2010.pdf

22. Tomaskova H., Mohelska H., Nemkova Z., 2011. Issues of financial literacy education, Procedia - Social and Behavioral Sciences, No. 28, pp. 365-369

23. World Bank, 2009. Diagnostic Review on Consumer Protection and Financial Literacy, http://web.worldbank.org/WBSITE/EXTERNAL/TOPICS/EXTFINANCIALSECTOR/0,,pr int:Y isCURL:Y contentMDK:21361393 pagePK:148956 piPK:216618 theSitePK:2828 85 isCURL:Y isCURL:Y,00.html\#diagnostic

24. Zvarikova K., Majerova J., 2014. Financial literacy in the Slovak Republic, Procedia Social and Behavioral Sciences, No. 110, pp. 1106-1115 